\title{
EVALUASI KINERJA BERDASARKAN STANDAR KOMPETENSI GURU PADA GURU KELAS DI SD NEGERI RANDUACIR 02
}

\author{
Wahyu Prasetyo ${ }^{1}, Y_{\text {ohana Setiawan }}^{2}$ \\ ${ }^{1}$ PGSD-FKIP-Universitas Kristen Satya Wacana \\ ${ }^{2}$ PGSD-FKIP-Universitas Kristen Satya Wacana
}

E-mail: ${ }^{1}$ wahyu.prasetyoriders.bsv@gmail.com, ${ }^{2}$ yohana.setiawan05@gmail.com

Receive: 18/03/2021

Accepted: 28/03/2021

Published: 28/03/2021

\begin{abstract}
Abstrak
Penelitian ini bertujuan untuk mengetahui kinerja guru kelas di SD Negeri Randuacir 02 berdasarkan standar kompetensi guru dari penilaian asesor (kepala sekolah), penilaian diri sendiri, dan penilaian teman sejawat. Jenis penelitian ini termasuk dalam penelitian evaluasi. Model yang digunakan adalah model benchmarking (bangku ukur). Teknik analisis yang digunakan adalah kuantitatif deskriptif. Populasi penelitian ini adalah guru kelas di SD Negeri Randuacir 02. Penelitian sampel guru kelas dilakukan dengan propotional random sampling sebanyak 6 guru. Teknik pengumpulan data menggunakan kuisioner. Dari 57 item terdapat 41 item dinyatakan valid, item- item tersebut memiliki koefisien corrected item to total correlation $\geq 0,20$, Hasil analisis kuesioner penilaian kinerja guru diperoleh alpha Cronbach's $=0,721$ sehingga dapat dikatakan memiliki reliabilitas pada kategori tinggi. Teknik analisis data menggunakan analisis statistik deskriptif dengan persentase. Hasil penelitian menunjukkan bahwa : (1) kompetensi pedagogik guru kelas di SD Negeri Randuacir 02 dalam kategori tinggi dengan rata-rata persentase sebesar $89,42 \%$. (2) kompetensi kepribadian guru kelas di SD Negeri Randuacir 02 dalam kategori tinggi dengan rata-rata persentase sebesar 92,3\%. (3) kompetensi sosial guru kelas di SD Negeri Randuacir 02 dalam kategori tinggi dengan rata-rata persentase 91,7\%. (4) kompetensi profesional guru kelas di SD Negeri Randuacir 02 dalam kategori tinggi dengan rata-rata persentase $94,4 \%$.
\end{abstract}

Kata Kunci: kompetensi pedagogik, kompetensi kepribadian, kompetensi sosial, kompetensi profesional

\begin{abstract}
This study aims to determine the performance of class teachers at SD Negeri Randuacir 02 based on teacher competency standards from assessors (school principal) assessments, self-assessments, and peer assessments. This type of research is included in evaluation research. The model used is the benchmarking model (measuring bench). The analysis technique used is descriptive quantitative. The study population was classroom teachers at SD Negeri Randuacir 02. The sample research for classroom teachers was carried out by using proportional random sampling of 6 teachers. The data collection technique used a questionnaire. Of the 57 items, 41 items were declared valid, these items had a corrected item to total correlation coefficient $\geq 0.20$. The results of the analysis of the teacher
\end{abstract}


performance appraisal questionnaire obtained Cronbach's alpha $=0.721$ so that it can be said to have reliability in the high category. The data analysis technique used descriptive statistical analysis with a percentage. The results showed that: (1) the pedagogical competence of class teachers at SD Negeri Randuacir 02 was in the high category with an average percentage of $89.42 \%$. (2) the personal competence of the class teachers at SD Negeri Randuacir 02 in the high category with an average percentage of 92.3\%. (3) the social competence of class teachers at SD Negeri Randuacir 02 in the high category with an average percentage of $91.7 \%$. (4) the professional competence of class teachers at SD Negeri Randuacir 02 is in the high category with an average percentage of $94.4 \%$.

Keywords: pedagogical competence, personality competence, social competence, professional competence.

\section{Pendahuluan}

Pada era globalisasi yang semakin maju, pendidikan menjadi salah satu hal penting yang harus diperhatikan. Pengembangan sistem pendidikan dapat dikatakan berhasil atau tidak dapat dilihat dari proses belajar mengajar. Pendidikan adalah pengalaman yang dibagikan terhadap seseorang atau kelompok dengan tujuan seseorang atau kelompok tersebut dapat mempelajari pengalaman yang diajarkan dan mengaplikasikannya dalam kehidupan. Hal ini senada dengan pendapat (Soekidtjo ,2003) yang mengatakan bahwa pendidikan merupakan rencana yang dilakukan oleh pelaku pendidikan untuk mempengaruhi orang lain baik individu, kelompok, atau masyarakat untuk melakukan apa yang diharapkan oleh pelaku pendidikan. Dalam hal ini guru menjadi inti dalam pendidikan, sebagai penyalur ilmu dalam menciptakan sumber daya manusia yang berkualitas. (Menurut Suparlan ,2008) Guru merupakan orang yang berupaya mencerdaskan kehidupan bangsa dalam dalam semua aspeknya baik emosional, intelektual, fisikal, spiritual maupun aspek lainnya. Dalam kata lain kinerja yang diberikan oleh guru sangat berpengaruh untuk mencapai tujuan pendidikan yang berkualitas.

Kinerja guru adalah hasil kerja yang dapat dicapai oleh seorang guru di lembaga pendidikan atau madrasah sesuai dengan tugas dan tanggung jawab dalam mencapai tujuan pendidikan (Asf \& Mustofa, 2013). Keberhasilan seorang guru harus memenuhi kriteria yang telah ditetapkan, apabila guru telah memenuhi kriteria tersebut berarti seorang guru dapat dikatakan berhasil dan memiliki kualitas yang baik. Sebaliknya apabila seorang guru belum memenuhi kriteria yang baik maka guru belum dapat dikatakan berhasil. Faktor-faktor yang mempengaruhi kinerja guru seseorang dapat berasal dari dalam individu itu sendiri seperti motivasi, keterampilan, dan juga pendidikan. Ada juga faktor dari luar individu seperti iklim kerja, tingkat gaji, dan lain sebagainya (Asf \& Mustofa, 2013). Ada beberapa masalah kinerja guru yang sering dijumpai pada saat kegiatan belajar mengajar. (Menurut Haryanto, 2000) rendahnya kinerja guru dapat dilihat dari fenomena-fenomena dilapangan antara lain masih ada sebagian guru yang kurang mampu menentukan metode pengajaran yang tepat, kurang menguasai materi yang diajarkan, kurang mampu membuat perencanaan pengajaran dengan baik, dan kurang terampil menggunakan media pembelajaran.Dalam Undang-Undang Nomor 14 Tahun 2005 pasal 10 ayat 1 disebutkan bahwa kompetensi yang harus dimiliki guru dibagi dalam 4 kelompok yaitu kompetensi pedagogik, kompetensi kepribadian, kompetensi sosial dan kompetensi profesional.

Penelitian yang dilakukan oleh (Ria Widarsih \& Nahiyah Jaidi Faraz,2016) dengan judul penelitian "Evaluasi Kinerja Guru IPS SMP berdasarkan Standar Kompetensi Guru di Kabupaten Kebumen" mendapat hasil bahwa (1) kompetensi pedagogik guru IPS SMP di Kabupaten Kebumen dalam kategori baik dengan persentase sebesar 88,00\%; (2) kompetensi kepribadian guru IPS SMP di Kabupaten Kebumen dalam kategori amat baik dengan 
persentase sebesar 93,09\%; (3) kompetensi sosial guru IPS SMP di Kabupaten Kebumen dalam kategori baik dengan persentase sebesar 88,65\%; dan (4) kompetensi profesional guru IPS SMP di Kabupaten Kebumen dalam kategori baik dengan persentase sebesar 79,53\%. Hal ini berarti bahwa kinerja guru IPS SMP di Kabupaten Kebumen berdasarkan kompetensi guru sudah sesuai dengan Permendiknas Nomor 16 Tahun 2007 tentang Standar Kualifkasi Akademik dan Kompetensi Guru..

Penelitian yang dilakukan oleh (Wishnu Hananta, 2017) dengan judul "Evaluasi Kinerja Guru Bersertifikat Pendidik di SD Negeri Tegalsari UPTD Pendidikan Kecamatan Karanggede Kabupaten Boyolali" Dalam penelitian ini evaluasi terhadap kinerja guru bersertifikat di SD Negeri Tegalsari pada kesiapan guru dalam penyusunan RPP dan bagaimana pelaksanaan pembelajaran yang dilakukan di kelas sudah dapat dikatakan baik, disini guru harus mampu menyusun RPP dengan baik dan melaksanakan pembelajaran sesuai dengan RPP yang sudah dibuat sehingga tujuan pembelajaran tercapai, guru memiliki kompetensi kepribadian dan kompetensi sosial yang baik, guru memiliki kemampuan dalam membimbing siswa untuk mengikuti lomba atau olimpiade sehingga prestasi siswa dapat ditekankan disini, dalam pembuatan modul dan media pembelajaran masih kurang maksimal dapat dilihat dari proses pembelajaran yang terkadang belum menggunakan media didalam pembelajaran.

\section{Metode}

Pendekatan, Jenis, Model Penelitian

Penelitian ini menggunakan pendekatan kuantitatif dengan analisis deskriptif. Menurut Sugiyono (2012) mengatakan bahwa metode analisis deskriptif adalah penelitian yang dilakukan untuk mengetahui nilai variabel mandiri, baik satu variabel atau lebih tanpa membuat perbandingan atau menghubungkan antara satu dengan variabel lain. Model evaluasi yang digunakan adalah evaluasi benchmarking (bangku ukur), hasil penelitian akan dibandingkan dengan standar kompetensi guru yang berlaku di Indonesia.

Subyek, Lokasi, dan Waktu Penelitian

Subyek penelitian ini meliputi kepala sekolah, guru, SD Negeri Randuacir 02 Salatiga. Penelitian ini akan dilakukan di SD Negeri Randuacir 02 Salatiga, Jln. Pertapaan Gedono nomor 61, Kelurahan Randuacir, Kecamatan Argomulyo, Salatiga, Jawa Tengah. Penelitian ini dilakukan pada bulan Februari sampai dengan selesai.

Teknik Pengumpulan Data

Penelitian ini menggunakan beberapa teknik pengumpulan data, yaitu :

\section{Angket}

Instrumen utama seperti angket, peneliti menggunakan lembar angket tertutup yang sudah disediakan jawabannya sehingga responden tinggal memilih. Sebelum menyusun instrumen, peneliti terlebih dahulu menyusun kisi-kisi untuk mempermudah pembuatan butir-butir instrumen dalam angket. Menurut Sugiyono (2012) Angket adalah teknik pengumpulan data yang dilakukan dengan cara memberi seperangkat pertanyaan atau pernyataan tertulis kepada responden untuk dijawabnya.

2. Observasi

Observasi merupakan proses memperoleh data yang dapat dilihat langsung, didengar, dan dapat dihitung (Riduwan, 2007:9). Observasi yang peneliti lakukan adalah obsevasi partisipasi moderat, yang berarti dalam mengumpulkan data peneliti ikut berpartisipasi dalam beberapa kegiatan yang diteliti namun tidak semua kegiatan diikuti (Sugiyono, 2017:108). Observasi dilakukan secara terbatas dikarenakan pandemi (COVID-19) peneliti melihat dokumen RPP dan mengikuti beberapa sesi kegiatan belajar mengajar secara online (daring).

Uji Validasi 
Pengujian validitas instrumen penilaian kinerja guru berdasarkan empat standar kompetensi guru dengan jumlah item sebanyak 57 pernyataan menggunakan pedoman suatu item valid atau tidak valid menggunakan ketentuan dari (Azwar ,2013) yang menyatakan bahwa item pada skala pengukuran dikatakan valid apabila mempunyai $\alpha>0,30$ Namun ketika jumlah item belum mencukupi jumlah jumlah yang diinginkan maka koefisien korelasi dapat diturunkan menjadi 0,25 atau 0,20 Dari 57 item terdapat 41 item dinyatakan valid, item- item tersebut memiliki koefisien corrected item to total correlation $\geq 0,20$.
Uji Reliabilitas

Hasil analisis kuesioner penilaian kinerja guru diperoleh alpha Cronbach's $=0,721$ sehingga dapat dikatakan memiliki reliabilitas pada kategori tinggi. Dengan demikian instrumen penelitian dapat dinyatakan item-itemnya valid dan reliabel untuk digunakan dalam mengukur kinerja karyawan.

\section{Hasil dan Pembahasan}

Analisis Deskriptif Penilaian Kinerja Guru dari Kepala Sekolah

\begin{tabular}{|c|c|c|c|c|}
\hline No. & Kategori & $\begin{array}{c}\text { Interval } \\
\text { Skor }\end{array}$ & Jumlah & Persentase \\
\hline 1 & Tinggi & 134-164 & 6 & $100 \%$ \\
\hline 2 & Sedang & 103-133 & $\mathbf{0}$ & $0 \%$ \\
\hline 4 & Rendah & $72-102$ & $\mathbf{0}$ & 0\% \\
\hline 5 & $\begin{array}{l}\text { Sangat } \\
\text { Rendah }\end{array}$ & 41-71 & $\mathbf{0}$ & $0 \%$ \\
\hline \multicolumn{3}{|c|}{ Jumlah } & 6 & $100 \%$ \\
\hline
\end{tabular}

Tabel 1

Penilaian Kinerja Guru dari Kepala Sekolah

Berdasarkan hasil perhitungan skor pada tabel tersebut dapat diketahui bahwa dari 6 guru kelas yang dinilai kepala sekolah, terdapat 6 guru (100\%) diantaranya memiliki kinerja dengankategori tinggi, 0 guru $(0 \%)$ diantaranya memiliki kinerja dengan kategori sedang, 0 guru $(0 \%)$ diantaranya memiliki kinerja dengan kategori rendah dan 0 guru $(0 \%)$ diantaranya memiliki kinerja dengan kategori sangat rendah. Maka didapatkan bahwa seluruh guru kelas memiliki penilaian kinerja yang tinggi dari kepala sekolah.

Analisis Deskriptif Penilaian Diri Sendiri

\begin{tabular}{|c|c|c|c|c|}
\hline No. & Kategori & Interval Skor & Jumlah & Persentase \\
\hline 1 & Tinggi & $134-164$ & 6 & $100 \%$ \\
\hline 2 & Sedang & $103-133$ & 0 & $0 \%$ \\
\hline
\end{tabular}




\begin{tabular}{|c|c|c|c|c|}
\hline 4 & Rendah & $72-102$ & 0 & $0 \%$ \\
\hline 5 & Sangat Rendah & $41-71$ & 0 & $0 \%$ \\
\hline \multicolumn{2}{|c|}{ Jumlah } & 6 & $100 \%$ \\
\hline
\end{tabular}

Tabel 2

Penilaian Diri Sendiri

Berdasarkan hasil perhitungan skor pada tabel tersebut dapat diketahui bahwa dari 6 guru kelas yang menilai diri sendiri , terdapat 6 guru $(100 \%)$ diantaranya memiliki kinerja dengan kategori tinggi, 0 guru $(0 \%)$ diantaranya memiliki kinerja dengan kategori sedang, 0 guru $(0 \%)$ diantaranya memiliki kinerja dengan kategori rendah dan 0 guru $(0 \%)$ diantaranya memiliki kinerja dengan kategori sangat rendah. Maka didapatkan bahwa seluruh guru kelas memiliki penilaian kinerja yang tinggi dari diri sendiri.

Analisis Deskriptif Penilaian Teman Sejawat

\begin{tabular}{|c|c|c|c|c|}
\hline No. & Kategori & Interval Skor & Jumlah & Persentase \\
\hline 1 & Tinggi & 134-164 & 30 & $100 \%$ \\
\hline 2 & Sedang & $103-133$ & $\mathbf{0}$ & $0 \%$ \\
\hline 4 & Rendah & $72-102$ & $\mathbf{0}$ & $0 \%$ \\
\hline 5 & Sangat Rendah & 41-71 & $\mathbf{0}$ & 0\% \\
\hline \multicolumn{3}{|c|}{ Jumlah } & 6 & $100 \%$ \\
\hline
\end{tabular}

Tabel 3

Penilaian Kinerja Guru dari Teman Sejawat

Berdasarkan hasil perhitungan skor pada tabel tersebut dapat diketahui bahwa dari 30 guru yang menilai teman sejawat, terdapat 30 guru $(100 \%)$ diantaranya memiliki kinerja dengan kategori tinggi, 0 guru $(0 \%)$ diantaranya memiliki kinerja dengan kategori sedang, 0 guru $(0 \%)$ diantaranya memiliki kinerja dengan kategori rendah dan 0 guru $(0 \%)$ diantaranya memiliki kinerja dengan kategori sangat rendah. Maka didapatkan bahwa seluruh guru kelas memiliki penilaian kinerja yang tinggi dari teman sejawat.

Konversi Penilaian Kinerja Guru Berdasarkan Empat Standar Kompetensi Guru..

\begin{tabular}{|c|c|c|c|c|}
\hline $\begin{array}{c}\text { Rentang } \\
\text { Nilai }\end{array}$ & Kategori & Asesor & $\begin{array}{c}\text { Diri } \\
\text { Sendiri }\end{array}$ & $\begin{array}{c}\text { Teman } \\
\text { Sejawat }\end{array}$ \\
\hline $134-164$ & Tinggi & $\mathbf{6}$ & $\mathbf{6}$ & 30 \\
\hline $103-133$ & Sedang & $\mathbf{0}$ & $\mathbf{0}$ & $\mathbf{0}$ \\
\hline $72-102$ & Rendah & $\mathbf{0}$ & $\mathbf{0}$ & $\mathbf{0}$ \\
\hline $41-71$ & Sangat & $\mathbf{0}$ & $\mathbf{0}$ & $\mathbf{0}$ \\
\hline
\end{tabular}




\begin{tabular}{|l|l|l|l|l|}
\hline & Rendah & & & \\
\hline
\end{tabular}

Tabel.4

Konversi Penilaian Kinerja Guru Berdasarkan Empat Standar Kompetensi

Berdasarkan tabel diatas penilaian asesor dalam kategori tinggi, menunjukkan bahwa penilaian kinerja guru sedangkan berdasarkan penilaian diri berdasarkan empat standar kompetensi guru sendiri dalam kategori tinggi dan penilaian di SD Negeri Randuacir 02 Salatiga teman sejawat dalam kategori tinggi.

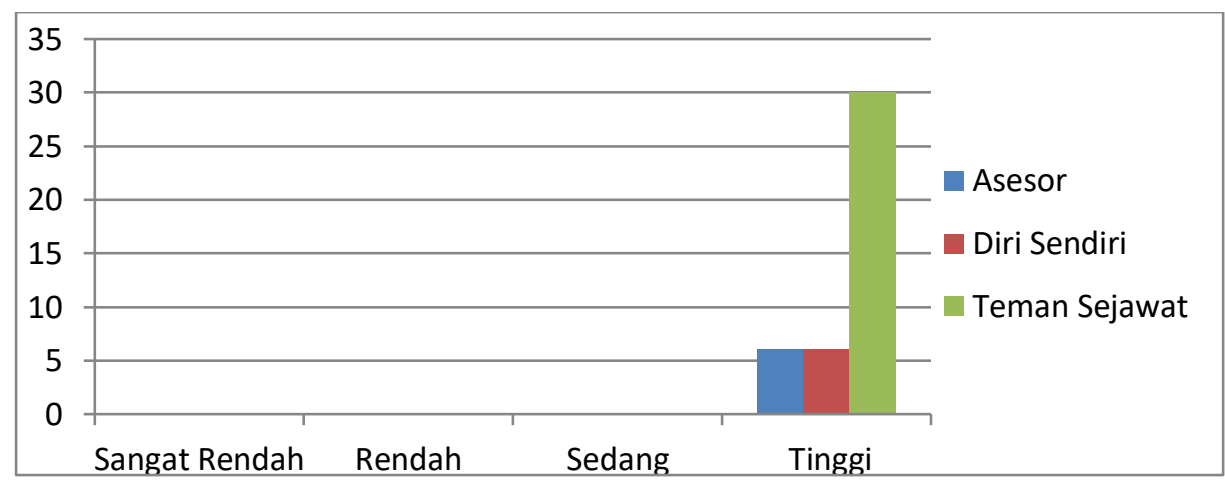

Gambar.1

Diagram Konversi Penilaian Kinerja Guru Berdasarkan Empat Standar Kompetensi Guru

Rekapitukasi Penilaian Kinerja Guru Berdasarkan 4 Standar Kompetensi Guru

Kompetensi Pedagogik

Kompetensi pedagogik terdiri dari 7 indikator dan 19 pernyataan. Berikut ini adalah tabel rekapitulasi penilaian kompetensi pedagogik di SD Negeri Randuacir 02 Salatiga.

\begin{tabular}{|l|c|c|c|}
\hline \multicolumn{1}{|c|}{ Pernyataan } & $\begin{array}{c}\text { Asesor } \\
(\%)\end{array}$ & $\begin{array}{c}\text { Diri } \\
\text { Sendiri } \\
(\%)\end{array}$ & $\begin{array}{c}\text { Teman } \\
\text { Sejawat } \\
(\%)\end{array}$ \\
\hline $\begin{array}{l}\text { 1. Guru kelas dapat menguasai teori belajar dan prinsip - prinsip } \\
\text { pembelajaran yang mendidik dalam pelaksanaan pembelajaran, } \\
\text { dengan contoh-contohnya. }\end{array}$ & 91,67 & 91,67 & 90,83 \\
\hline $\begin{array}{l}\text { 2. Guru kelas dapat mengetahui kesulitan belajar peserta didik } \\
\text { dalam pelajaran yang diampu. }\end{array}$ & 87,5 & 87,5 & 86,67 \\
\hline $\begin{array}{l}\text { 3. Guru kelas dapat mengenali potensi (kemampuan,minat,bakat) } \\
\text { peserta didik dalam mata pelajaran yangdiampu. }\end{array}$ & 91,67 & 95,83 & 95 \\
\hline
\end{tabular}




\begin{tabular}{|c|c|c|c|}
\hline $\begin{array}{l}\text { 4. Guru kelas dapat mengenal karakteristik (ciri-ciri,sifat-sifat) } \\
\text { peserta didik. }\end{array}$ & 87,5 & 95,8 & 93,3 \\
\hline $\begin{array}{l}\text { 5. Guru kelas dapat menentukan "tujuan } \\
\text { pengalaman belajar yang sesuai" untuk melajaran dan } \\
\text { pembelajaran. }\end{array}$ & 87,5 & 83,33 & 85 \\
\hline $\begin{array}{l}\text { 6. Guru kelas dapat menata materi pembelajaran secara benar sesuai } \\
\text { dengan metode yang dipilih dan karakteristik (sifat, bakat) peserta } \\
\text { didik. }\end{array}$ & 83,3 & 87,5 & 85 \\
\hline $\begin{array}{l}\text { 7. Guru kelas merencanakan strategi pembelajaran dengan } \\
\text { memanfaatkan sumber daya yang ada }\end{array}$ & 79,2 & 91,7 & 96,7 \\
\hline $\begin{array}{l}\text { 8. Guru kelas menyusun rancangan pembelajaran sesuai dengan } \\
\text { kompetensi inti dan kompetensi dasar. }\end{array}$ & 87,5 & 91,7 & 90 \\
\hline $\begin{array}{l}\text { 9. Guru kelas menyesuaikan rancangan pembelajaran dengan } \\
\text { cakupan materi yang ada (cakupan materi /konsep dan alokasi } \\
\text { waktu) }\end{array}$ & 91,7 & 87,5 & 87,5 \\
\hline $\begin{array}{l}\text { 10. Guru kelas menggunakan beragam media untuk memper mudah } \\
\text { proses pembelajaran untuk meningkatkan motivasi belajar siswa }\end{array}$ & 91,7 & 87,5 & 85 \\
\hline $\begin{array}{l}\text { 11. Guru kelas mengajak peserta didik untuk ambil bagian dalam } \\
\text { pembicaraan di kelas sesuai tujuan pembelajaran . }\end{array}$ & 87,5 & 87,5 & 93,33 \\
\hline $\begin{array}{l}\text { 12. Guru kelas merespon pertanyaan dan jawaban siswa, baik yang } \\
\text { benar maupun yang salah, agar siswa tidak bingung. }\end{array}$ & 91,67 & 83,33 & 92,5 \\
\hline $\begin{array}{l}\text { 13. Guru kelas melakukan evaluasi terhadap proses pembelajaran } \\
\text { menggunakan berbagai jenis teknik penilaian }\end{array}$ & 87,5 & 87,5 & 85 \\
\hline $\begin{array}{l}\text { 14. Guru kelas mengumumkan hasil evaluasi proses pembelajaran } \\
\text { kepada pesertadidik }\end{array}$ & 91,67 & 83,33 & 91,67 \\
\hline $\begin{array}{l}\text { 15. Guru kelas menerapkan prinsip-prinsip serta aspek-aspek yang } \\
\text { berkaitan dengan penilaian dan evaluasi proses dan hasil belajar } \\
\text { sesuai dengan karakteristik mata pelajaran. }\end{array}$ & 87,5 & 79,2 & 86,7 \\
\hline $\begin{array}{l}\text { 16. Guru kelas selalu membimbing peserta didik dalam proses } \\
\text { pembelajaran sesuai dengan cara belajarnya masing-masing. }\end{array}$ & 100 & 91,7 & 93,3 \\
\hline $\begin{array}{l}\text { 17. Guru kelas menganalisis hasil belajar untuk mengetahui taraf } \\
\text { kemajuan masing-masing peserta didik. }\end{array}$ & 91,7 & 87,5 & 88,3 \\
\hline $\begin{array}{l}\text { 18. Guru kelas merancang dan melaksanakan aktivitas pembelajaran } \\
\text { yang mendorong peserta didik agar belajar menurut kecakapan dan } \\
\text { kemampuan masing-masing. }\end{array}$ & 100 & 100 & 97,5 \\
\hline $\begin{array}{l}\text { 19. Guru kelas menyediakan berbagai kegiatan pembelajaran, untuk } \\
\text { memperlihatkan potensi peserta didik, termasuk kreativitasnya. }\end{array}$ & 83,33 & 91,67 & 81,67 \\
\hline KOMPETENSI PEDAGOGIK & 89,47 & 89,04 & 89,74 \\
\hline
\end{tabular}

Tabel.5

Rekapitulasi Penilaian Kinerja Guru berdasarkan Kompetensi Pedagogik

Berdasarkan tabel diatas dapat diketahui bahwa berdasarkanpenilaian dari asesor untuk penilaian pada kompetensi pedagogik sebesar $89,47 \%$, sedangkan untuk penilaian diri sendiri pada kompetensi pedagogik sebesar $89,04 \%$, dan untuk penilaian teman sejawat pada kompetensi pedagogik sebesar 89,74\%. Jika dirata-rata maka hasilnya adalah $89,42 \%$ dan termasuk pada kategori tinggi. Hal ini 
menunjukkan bahwa kinerja guru SD Negeri Randuacir 02 Salatigapada kompetensi pedagogik sesuai dengan Undang-Undang No. 14 tahun 2015 tentang guru dan dosen, kinerja guru dapat ditunjukan dari seberapa besar kompetensikompetensi yang dipersyaratkan dipenuhi.

Kompetensi Kepribadian

Kompetensi kepribadian terdiri dari 4 indikator dan 8 pernyataan. Berikut ini adalah tabel rekapitulasi penilaian kompetensi kepribadian di SD Negeri Randuacir 02 Salatiga.

\begin{tabular}{|l|c|c|c|c|}
\hline \multicolumn{1}{|c|}{ Pernyataan } & $\begin{array}{l}\text { Assesor } \\
(\%)\end{array}$ & $\begin{array}{l}\text { Diri } \\
\text { sendiri } \\
(\%)\end{array}$ & $\begin{array}{l}\text { Teman } \\
\text { Sejawat } \\
(\%)\end{array}$ \\
\hline \begin{tabular}{|l|c|c|} 
1. Guru kelas berpenampilan bersih dan rapi pada saat \\
mengajar
\end{tabular} & 83,33 & 91,67 & 81,67 \\
\hline $\begin{array}{l}\text { 2. Guru kelas bertutur kata yang baik saat didalam } \\
\text { maupun luar kelas }\end{array}$ & 87,5 & 83,3 & 88,3 \\
\hline $\begin{array}{l}\text { 3.Guru kelas melakukan perbuatan baik sesuai dengan } \\
\text { yang dinasehatkan kepada peserta didik }\end{array}$ & 87,5 & 87,5 & 91,7 \\
\hline $\begin{array}{l}\text { 4.Guru kelas dapat berkomunikasi secara efektif, } \\
\text { empatik dan santun dialam dan diluar lingkungan } \\
\text { sekolah }\end{array}$ & 100 & 95,83 & 91,67 \\
$\begin{array}{l}\text { 5.Guru kelas sering meninggalakan kelas pada saat jam } \\
\text { pelajaran belumberakhir }\end{array}$ & 95,8 & 95,8 & 92,5 \\
\hline $\begin{array}{l}\text { 6.Guru kelas melakukan kegiatan untuk mengisi waktu } \\
\text { luang secara bijaksana dan produktif. }\end{array}$ & 95,8 & 95,8 & 90,8 \\
\hline $\begin{array}{l}\text { T. Guru kelas mengajar didalam kelas dengan penuh } \\
\text { rasa percaya diri }\end{array}$ & 91,67 & 91,67 & 95 \\
\hline $\begin{array}{l}\text { 8. Guru kelas dapat melakukan improvisasi saat } \\
\text { pembelajaran }\end{array}$ & 95,8 & 91,7 & 93,3 \\
\hline \begin{tabular}{l} 
KOMPETENSI KEPRIBADIAN \\
\hline
\end{tabular}
\end{tabular}

Rekapitulasi Penilaian Kinerja Guru berdasarkan Kompetensi Kepribadian

Berdasarkan tabel diatas dapat diketahui bahwa berdasarkan penilaian dari asesor untuk penilaian pada kompetensi kepribadian sebesar 93,2\%, sedangkan untuk penilaian diri sendiri pada kompetensi kepribadian sebesar 92,2\%, dan untuk penilaian teman sejawat pada kompetensi kepribadian sebesar 91,6\%. Jika dirata-rata maka hasilnya adalah 92,3\% dan termasuk pada kategori tinggi. Hal ini menunjukkan bahwa kinerja guru SD Negeri Randuacir 02 Salatigapada kompetensi kepribadian sesuai dengan Undang-Undang No. 14 tahun 2015 tentang guru dan dosen, kinerja guru dapat ditunjukan dari seberapa besar kompetensikompetensi yang dipersyaratkan dipenuhi

\section{Kompetensi Sosial}

Kompetensi sosial terdiri dari 3 indikator dan 7 pernyataan. Berikut ini adalah tabel rekapitulasi penilaian kompetensi sosal di SD Negeri Randuacir 02 Salatiga. 


\begin{tabular}{|c|c|c|c|}
\hline Pernyataan & $\begin{array}{c}\text { Asesor } \\
(\%)\end{array}$ & $\begin{array}{l}\text { Diri } \\
\text { Sendiri } \\
(\%)\end{array}$ & $\begin{array}{c}\text { Teman } \\
\text { Sejawat }(\%)\end{array}$ \\
\hline $\begin{array}{l}\text { 1. Guru kelas tidak pernah memberikan peluang kepada peserta } \\
\text { didik untuk mengemukakanpendapat }\end{array}$ & 91,7 & 95,8 & 89,2 \\
\hline $\begin{array}{l}\text { 2. Guru kelas berkomunikasi dengan peserta didik tanpa } \\
\text { membeda-bedakan satu samalain. }\end{array}$ & 91,7 & 87,5 & 89,2 \\
\hline $\begin{array}{l}\text { 3. Guru kelas dapat memberikan instruksi dengan jelas kepada } \\
\text { peserta didik melalui tulisan }\end{array}$ & 83,3 & 87,5 & 90,8 \\
\hline $\begin{array}{l}\text { 4. Guru kelas memberikan kesempatan kepada peserta didik } \\
\text { untuk berkomunikasi melalui media sosial terkait mata } \\
\text { pelajaran }\end{array}$ & 95,8 & 87,5 & 93,3 \\
\hline $\begin{array}{l}\text { 5. Guru kelas dapat melakukan pembelajaran dengan } \\
\text { memanfaatkan teknologi }\end{array}$ & 91,67 & 91,67 & 90 \\
\hline $\begin{array}{l}\text { 6.Guru kelas membedakan sikap kepada peserta didik yang } \\
\text { kurang mampu dan memiliki intelegensi yang rendah }\end{array}$ & 100 & 95,83 & 96,67 \\
\hline $\begin{array}{l}\text { 7.Guru kelas menyampaikan informasi tentang kemajuan, } \\
\text { kesulitan, dan potensi peserta didik kepada orang tua }\end{array}$ & 95,83 & 91,67 & 90 \\
\hline KOMPETENSI SOSIAL & 92,9 & 90,5 & 91,7 \\
\hline
\end{tabular}

Tabel.7

Rekapitulasi Penilaian Kinerja Guru berdasarkan Kompetensi Kepribadian

Berdasarkan tabel diatas dapat diketahui bahwa berdasarkan penilaian dari asesor untuk penilaian pada kompetensi sosial sebesar $92,9 \%$, sedangkan untuk penilaian diri sendiri pada kompetensi sosial sebesar $90,5 \%$, dan untuk penilaian teman sejawat pada kompetensi sosial sebesar $91,7 \%$. Jika dirata-rata maka hasilnya adalah $91,7 \%$ dan termasuk pada kategori tinggi. Hal ini menunjukkan bahwa kinerja guru SD Negeri Randuacir 02 Salatigapada kompetensi sosial sesuai dengan Undang-Undang No. 14 tahun 2015 tentang guru dan dosen, kinerja guru dapat ditunjukan dari seberapa besar kompetensikompetensi yang dipersyaratkan dipenuhi.

\section{Kompetensi Profesional}

Kompetensi profesional terdiri dari 3 indikator dan 7 pernyataan. Berikut ini adalah tabel rekapitulasi penilaian kompetensi profesional di SD Negeri Randuacir 02 Salatiga.

\begin{tabular}{|l|c|c|c|}
\hline Pernyataan & $\begin{array}{c}\text { Asesor } \\
(\%)\end{array}$ & $\begin{array}{c}\text { Diri } \\
\text { Sendiri } \\
(\%)\end{array}$ & $\begin{array}{c}\text { Teman } \\
\text { Sejawat } \\
(\%)\end{array}$ \\
\hline $\begin{array}{l}\text { 1. Guru kelas menguasai, terampil dan lancar dalam } \\
\text { mengimplementasikan K13 pada proses } \\
\text { pembelajaran }\end{array}$ & 87,5 & 91,7 & 95 \\
\hline $\begin{array}{l}\text { 2. Guru kelas merespon pertanyaan atau pendapat } \\
\text { peserta didik dengan baik }\end{array}$ & 100 & 100 & 98 \\
\hline
\end{tabular}




\begin{tabular}{|l|c|c|c|}
\hline $\begin{array}{l}\text { 3. Guru kelas memahami materi pelajaran yang } \\
\text { diajarkan secara mendalam }\end{array}$ & 95,8 & 100 & 100 \\
\hline $\begin{array}{l}\text { 4. Guru kelas tidak merencanakan dan merancang } \\
\text { pembelajaran yang kreatif }\end{array}$ & 95,8 & 100 & 95,8 \\
\hline $\begin{array}{l}\text { 5. Guru kelas merumuskan indikator pembelajaran } \\
\text { dengan menyesuaikan proses dan hasil belajar yang } \\
\text { diharapkan untuk dicapai }\end{array}$ & 87,5 & 91,7 & 91,7 \\
\hline $\begin{array}{l}\text { 6.Guru kelas memilih media pembelajaran sesuai } \\
\text { dengan materi pembelajaran dikehidupan sehari-hari } \\
\text { dan pendekatan pembelajaran yang ada pada } \\
\text { kurikulum 2013 (Pendekatan berbasis keilmuan) }\end{array}$ & 95,8 & 87,5 & 91,5 \\
\hline $\begin{array}{l}\text { 7. Guru kelas meminta peserta didik untuk } \\
\text { menerapkan pembelajaran dalam kehidupan sehari- } \\
\text { hari }\end{array}$ & 91,67 & 95,83 & 89,17 \\
\hline $\begin{array}{l}\text { KOMPETENSI PROFESIONAL } \\
\text { KOMala }\end{array}$ & 93,5 & 95,2 & 94,4 \\
\hline
\end{tabular}

Tabel.8

Rekapitulasi Penilaian Kinerja Guru berdasarkan Kompetensi Kepribadian

Berdasarkan tabel diatas dapat diketahui bahwa berdasarkan penilaian dari asesor untuk penilaian pada kompetensi profesional sebesar 93,5\%, sedangkan untuk penilaian diri sendiri pada kompetensi profesional sebesar 95,2\%, dan untuk penilaian teman sejawat pada kompetensi profesional sebesar 94,4\%. Jika dirata-rata maka hasilnya adalah $94,4 \%$ dan

\section{Pembahasan}

Penelitian ini bertujuan untuk mengetahui kinerja guru kelas berdasarkan empat kompetensi standar guru yaitu kompetensi pedagogik, kompetensi kepribadian, kompetensi sosial, dan kompetensi profesional di SD Negeri Randuacir 02. Berdasarkan dari hasil penelitian yang diperoleh, dapat dianalisis bahwa kinerja guru di SD Negeri Randuacir 02 Salatiga yang ditinjau dari kompetensi pedagogik mendapakan persentase berdasarkan penilaian dari asesor untuk penilaian pada kompetensi pedagogik sebesar $89,47 \%$, sedangkan untuk penilaian diri sendiri pada kompetensi pedagogik sebesar $89,04 \%$, dan untuk penilaian teman sejawat pada kompetensi pedagogik sebesar termasuk pada kategori tinggi. Hal ini menunjukkan bahwa kinerja guru SD Negeri Randuacir 02 Salatigapada kompetensi profesional sesuai dengan Undang-Undang No. 14 tahun 2015 tentang guru dan dosen, kinerja guru dapat ditunjukan dari seberapa besar kompetensikompetensi yang dipersyaratkan dipenuhi.

$89,74 \%$. Jika dirata-rata maka hasilnya adalah $89,42 \%$ dan termasuk pada kategori tinggi. Hal ini menunjukkan bahwa kinerja guru SD Negeri Randuacir 02 Salatigapada kompetensi pedagogik sesuai dengan Undang-Undang No. 14 tahun 2015 tentang guru dan dosen, kinerja guru dapat ditunjukan dari seberapa besar kompetensikompetensi yang dipersyaratkan dipenuhi.

Pada kompetensi kepribadian menunjukkan penilaian dari asesor untuk penilaian pada kompetensi kepribadian sebesar 93,2\%, sedangkan untuk penilaian diri sendiri pada kompetensi kepribadian sebesar $92,2 \%$, dan untuk penilaian teman sejawat pada kompetensi kepribadian sebesar 91,6\%. Jika dirata-rata maka hasilnya adalah $92,3 \%$ dan termasuk pada 
kategori tinggi. Hal ini menunjukkan bahwa kinerja guru SD Negeri Randuacir 02 Salatigapada kompetensi kepribadian sesuai dengan Undang-Undang No. 14 tahun 2015 tentang guru dan dosen, kinerja guru dapat ditunjukan dari seberapa besar kompetensikompetensi yang dipersyaratkan dipenuhi.

Pada kompetensi sosial
menunjukkan penilaian dari asesor untuk penilaian pada kompetensi sosial sebesar $92,9 \%$, sedangkan untuk penilaian diri sendiri pada kompetensi sosial sebesar $90,5 \%$, dan untuk penilaian teman sejawat pada kompetensi sosial sebesar 91,7\%. Jika dirata-rata maka hasilnya adalah $91,7 \%$ dan termasuk pada kategori tinggi. Hal ini menunjukkan bahwa kinerja guru SD Negeri Randuacir 02 Salatigapada kompetensi sosial sesuai dengan UndangUndang No. 14 tahun 2015 tentang guru dan dosen, kinerja guru dapat ditunjukan dari seberapa besar kompetensi-kompetensi yang dipersyaratkan dipenuhi.

Sedangkan pada kompetensi profesional menunjukkan penilaian dari asesor untuk penilaian pada kompetensi profesional sebesar 93,5\%, sedangkan untuk penilaian diri sendiri pada kompetensi profesional sebesar 95,2\%, dan untuk penilaian teman sejawat pada kompetensi profesional sebesar 94,4\%. Jika dirata-rata maka hasilnya adalah $94,4 \%$ dan termasuk pada kategori tinggi. Hal ini menunjukkan bahwa kinerja guru SD Negeri Randuacir 02 Salatigapada kompetensi profesional sesuai dengan Undang-Undang No. 14 tahun 2015 tentang guru dan dosen, kinerja guru dapat ditunjukan dari seberapa besar kompetensikompetensi yang dipersyaratkan dipenuhi. Berdasarkan hasil analisis deskriptif dari seluruh keempat kompetensi guru yaitu kompetensi pedagogik, kompetensi kepribadian, kompetensi sosial, kompetensi profesional yang dilakukan oleh asesor, diri sendiri, dan teman sejawat menunjukkan bahwa kinerja guru SD Negeri Randuacir 02 Salatiga berada pada kategori tinggi.

Hasil penelitian ini mendukung hasil penelitian Ria Widarsih \& Nahiyah
Jaidi Faraz (2016) dengan judul penelitian "Evaluasi Kinerja Guru IPS SMP berdasarkan Standar Kompetensi Guru di Kabupaten Kebumen" mendapat hasil bahwa (1) kompetensi pedagogik guru IPS SMP di Kabupaten Kebumen dalam kategori baik dengan persentase sebesar 88,00\%; (2) kompetensi kepribadian guru IPS SMP di Kabupaten Kebumen dalam kategori amat baik dengan persentase sebesar 93,09\%; (3) kompetensi sosial guru IPS SMP di Kabupaten Kebumen dalam kategori baik dengan persentase sebesar $88,65 \%$; dan (4) kompetensi profesional guru IPS SMP di Kabupaten Kebumen dalam kategori baik dengan persentase sebesar 79,53\%. Hal ini berarti bahwa kinerja guru IPS SMP di Kabupaten Kebumen berdasarkan kompetensi guru sudah sesuai dengan Permendiknas Nomor 16 Tahun 2007 tentang Standar Kualifikasi Akademik dan Kompetensi Guru.

Ada beberapa faktor yang mempengaruhi kinerja guru, menurut Malthis dan Jackson dalam Jasmani (2013) ada tiga faktor yang mempengaruhi kinerja karyawan (guru), yaitu kemampuan, usaha yang dicurahkan, dan dukungan organisasi. Kinerja (Performance/P) $=$ Kemampuan (ability/A) x Usaha (effort/E) x Dukungan (Support/S). Dengan begitu kinerja seorang guru akan meningkat apabila ketiga komponen tersebut ada dalam dirinya, dan akan kurang jika salah satu komponen tersebut kurang bahkan tidak ada. Ketiga komponen tersebut sudah dipenuhi guru yang ada pada SD Negeri Randuacir 02 Salatiga sehingga kinerja guru berada pada kategori tinggi, artinya kinerja guru SD Negeri Randuacir 02 Salatiga sudah baik dan sesuai dengan empat standar kompetensi guru. Hal ini juga dibuktikan dengan akreditasi Ayang dimiliki SD Negeri Randuacir 02 Salatiga.

\section{Saran}

Untuk mempertahankan kinerja guru berdasarkan empat standar kompetensi guru, guru yang sudah memiliki nilai baik dapat memberikan bimbingan kepada guru 
dan pada sekolah yang lain. Seiring dengan kemajuan zaman guru yang masih kurang dalam hal teknologi diharapkan dapat menyesuaikan dengan perkembangan teknologi agar dapat menyesuaikan pembelajaran sesuai yang diharapkan.

\section{Daftar Pustaka}

Arikunto\& Suharsami. (2010). Manajemen Penelitian. Jakarta: PT. Rineka Putra

Jasmani\& Syaiful, M.,(2013). Supervisi Pendidikan: Terobosan Baru dalam Peningkatan Kinerja Pe ngawas Sekolah dan Guru. Jokjakarta: ArRuzz Media.

Azwar, S., (2013). Skala Psikologi. Yogyakarta: Pustaka Pelajar.

Departemen Pendidikan Nasional, 2005. Undang-Undang Nomor 14 Tahun 2005, Tentang Guru dan Dosen, Jakarta: Depdiknas.

Diah,M.W., dkk. 2007. "Evaluasi Kinerja Guru Bersertifikat Pendidik di SD Negeri Tegalsari UPTD Pendidikan Kecamatan Karanggede Kabupaten Boyolali”. Tesis. Fakultas Keguruan Dan Ilmu Pendidikan. Program Pascasarjana Magister Teknologi Pendidikan. Universitas Lampung. Bandar Lampung

Herdiansyah, H.,(2015). Wawancara, Observasi, dan Focus Groups Sebagai Instrumen

Indra, H.,(2014) Sindang Lurah Peran Kepala Sekolah Dalam Penerapan Manajemen Berbasis Sekolah (MBS) Di Sdit Jabal Nur Gamping, Sleman. Jurnal Akuntabilitas Manajemen Pendidikan 2. No. 2 (1 September 2014).

Https://Doi.Org/10.21831/Amp.V2i2. 2447.
Notoatmodjo, S., (2008), Metodologi Penelitian Kesehatan. Edisi revisi. Jakarta: PT. Rineka Cipta.

Penggalian Data Kualitatif. Depok: PT. Rajadrafindo Persada.

Ramli. (2013). Evaluasi Kinerja Guru Sekolah Menengah Kejuruan Sumatera Barat Pascasertifikasi. Jurnal Penelitian dan Evaluasi Pendidikan. Vol 17 No 1. (diakses paa tanggal 7 Februari 2021)

Sugiyono (2015). Metode Penelitian Kombinasi (Mix Methods). Bandung: Alfabeta.

Sugiyono. (2018). Metode Penelitian Kombinasi (Mixed Methods). Bandung: CV Alfabeta.

Sugiyono. (2012). Metode Penelitian Kuantitatif Kualitatif dan R\&B. Bandung: Alfabeta.

Suparlan.(2008), Menjadi Guru Efektif, Jakarta: Hikayat Publishing.

Syamsuin. (2015). Evaluasi Kinerja Guru Sekolah dasar di Kutai Timur. Vol 3 No 2. (diakses pada tanggal 7 Februari 2021)

UU No. 14 tahun 2005 tentang Guru dan Dosen.

Widarsih. (2016). Evaluasi Kinerja Guru Ips Smp Berdasarkan Standar Kompetensi Guru Di Kabupaten Kebumen. Jurnal Harmoni Sosial. Vol 3 No 2. (diakses pada tanggal 7 Februari 2021)

Wishnu, H., (2017). "Evaluasi Kinerja Guru Bersertifikat Pendidik di SD Negeri Tegalsari UPTD Pendidikan Kecamatan Karanggede Kabupaten Boyolali”. Tesis. Fakultas Keguruan Dan Ilmu Pendidikan. Program Studi Magister Manajemen Pendidikan. 
Universitas Kristen Satya Wacana. Yamin, M.\& Maisah. (2010). Standarisasi Salatiga Kinerja Guru. Jakarta: Persada Press. 